\title{
How Sensitive are Indonesian Customers to Sexual Appeal Advertising? (A Study of the Axe TV Commercial, "Heaven on Earth")
}

\author{
Diana Sari \\ Department of Management \& Business Padjadjaran University, Bandung, Indonesia \\ diana.sari@fe.unpad.ac.id \\ Winton \\ Department of Management \& Business Padjadjaran University, Bandung, Indonesia \\ officialwinton@gmail.com \\ Philip Trebilcock \\ Department of Economics Business \& Law La Trobe University, Bendigo, Australia \\ p.trebilcock@latrobe.edu.au
}

\section{Doi:10.5901/mjss.2015.v6n2s5p149}

\begin{abstract}
Previous studies have shown somewhat of a contradiction in the effect of sexual appeal advertising on purchase intention. This research aims to examine from an Indonesian perspective the consumer response to sexual appeal advertising and the subsequent purchase intention toward the products advertised. Through advertising, companies seek to be seen as the providers of creative and innovative products. Therefore company success increasingly relies on advertising appeal. One of these appeals is sexual advertising that is considered to be uniquely able to attract the attention of consumers and strengthen the brand with favorable associations. Such appeal eventually influences purchase decisions and stimulates purchase intention. This research uses quantitative methods through a consumer survey and simple regression analysis. Samples included 120 heterosexual men in the 15-24 year age group who reside in Indonesia's third largest city, Bandung. Results show that the consumer response to sexual appeal advertising of AXE is positive and consumer purchase intention of AXE products after watching the "Heaven on Earth" advertisements series is strongly positive. Sexual appeal advertising is shown to have a statistically significant positive effect on Indonesian consumers' purchase intentions.
\end{abstract}

Keywords: Advertising, Sexual Appeal Advertising, Purchase Intention

\section{Introduction}

Appropriate advertising plays an increasingly significant role in the marketing activities of companies facing industry competition. Advertising has been considered one of the most effective means of providing information on company products and in the attraction of new customers to the firm. To win against industry competition and capture market share, companies cannot operate in an environment of half-hearted advertising spending. Nielsen Advertising Information Services (2013) indicated that Indonesian media spending reached Rp 51. 2 trillion in the first half of 2013. This showed a $25 \%$ increase in the national media spending in the first half of 2013 compared to the same period in the previous year, and a 130\% increase over the same period in 2009.

One effective advertising medium in conveying a message and affecting consumers is television. Nielsen Advertising Information Services (2013) calculated that in the first half of 2013 , television media advertising contributed approximately $68 \%$ of total ad spend. Kotler and Keller (2012: 670) state that the television advertising has a significant advantage in that it has a broad range that combines image, sound, and motion to stimulate the senses and heighten attention. Television advertising has grown from just display images and communication about the product. It now relies on a wider range of appeal to attract attention. According to Belch and Belch (2009: 283), advertising now contains a kind of fascination that includes informational/rational appeal, but also emotional appeal expressed in fear, humor, or sex.

A significant appeal often used by advertisers is sexual. 'Sex sells' is a trusted philosophy used by several marketers in the pursuit of marketing their products. Sexual appeal advertising is thus one application of the philosophy of 
"sex sells". The assumption is that consumers are motivated by advertising using sexual and provocative imagery. Furthermore, some marketers will blend sexual appeal with other elements of Belch and Belch's (2009) analysis with often subtle blends of humor or fear. Sexual appeal advertising seeks to attract the attention of consumers and strengthen brand associations. Advertising seeks to attract consumer attention and ultimately influence buying behavior. Buying intention can measure the likelihood of a consumer to buy a product. The higher the consumer interest in a product, the higher will be the consumer desire to buy that product.

In 1983, $15 \%$ of advertisements used sex as a selling point. That number increased to $27 \%$ in 2003 . Out of 18 categories of products, the most frequent use of sexual imagery in advertising was in health and hygiene products at $38 \%$, beauty $36 \%$, drugs and medicines $29 \%$, clothing 27\%, travel 23\%, and entertainment 21\% (Reichert, businessnewsdaily. com : 2012). One company that extensively uses sexual appeal in advertising is PT. Unilever Indonesia Tbk (Unilever). In particular, and for the purposes of this research, Unilever uses sexual appeal advertising for the promotion of its AXE range of products.

AXE is a male grooming product first launched in 1983 in France. The AXE brand has now become one of the leaders of male grooming products in more than 60 countries. In Indonesia AXE occupies market leadership winning Indonesia's Favorite Youth Brand 2013 in the perfume/ body spray/ body mist (male) product category. AXE advertisements regularly attract attention. AXE has won the Cannes Lions Advertising Awards more than ten times. One of the series of Indonesian AXE advertisements that have attracted the most attention is the series, "Heaven on Earth". This series follows the AXE message promoted by bikini-clad women in our countries that using AXE products prompts sexual attraction. The series of Indonesian advertisements illustrate that by using AXE products men can captivate an angel to fall from heaven.

The main advertisement begins with a scene whereby a young Indonesian man applies AXE products before going to bed. After falling asleep, the man is woken by a beautiful female winged-angel seductively pulling back his bed sheet and lying next to him. Further angels appear that playfully engage with the man and each other. The angels massage the man's head and shoulders, mix drinks for him and entice him with a soapy and alluring sponge-wash. The advertisement ends with a display of AXE products and a message printed across the screen that states that AXE products have a sexy fragrance.

By using the AXE "Heaven on Earth" series of advertisements, this study seeks to determine the effect of sexual advertising on Indonesian consumers.

\section{Literature Review}

According to Kotler and Keller (2012: 478), advertisements are any paid form of non-personal presentations and promotion of ideas, goods, or services by an identified sponsor. Advertisements have the capacity to reach consumers who are geographically dispersed (Kotler and Keller, 2012: 490). Advertising can build image in the long term for a product or trigger quick sales. Certain forms of advertising, such as TV advertising, require large budgets, while other forms of advertising such as newspapers do not. The mere presence of an advertisement can have an effect on sales. Consumers trust brands extensively advertised. Television is generally recognized as the most powerful advertising medium and reaches a broad spectrum of consumers with low cost per unit exposure. TV advertisement properly designed and implemented can be a powerful marketing tool that can increase brand equity and positively impact on sales and profits.

The appeal of advertising and execution typically rely on one another, so that a certain appeal can be exercised through a variety of ways and can be applied to a particular execution in a wide range of appeal advertisements (Belch and Belch, 2009: 283). Belch and Belch (2009: 283) classify the types of advertising appeal as informational/rational appeal; and emotional appeal which also includes the appeals of fear, humor and sex. Sexual advertising appeal can be described as sexuality in the form of nudity, sexual imagery and innuendo used as an advertising tool for a wide range of products. Formally sexual appeal advertising was defined as mediated message (i. e. in commercial TV ads and magazine ads) containing sexual information with the goal of persuasive selling of branded goods. Sexual information itself is content with sexual meaning that is considered as the source (Reichert, 2002: 243).

Lin (1998: 467-468) reveals that the advertising power of sexual attraction consists of three dimensions, namely the physical characteristics, sexually oriented conduct, and the model's sex appeal.

1. Physical Characteristics: the characteristics or elements such as approximate age, physical shape and the clothing revealed by the model;

2. Sexually Oriented Conduct: behavior consisting of three elements, namely physical innuendo, verbal innuendo and physical contact; 
3. The Model's Sex Appeal: The sexual attractiveness of the model him/herself, consisting of three elements, namely physical attractiveness, sexiness and sexual objects involved.

In addition to creating an emotional connection with consumers through sexual appeal advertising, marketers seek the onset of behavioral responses. These responses are sought in behavior that ultimately leads to the purchase of advertised products. The ultimate goal then of advertising is to influence consumers to buy the advertised product and increase company sales.

Schiffman, Kanuk, \& Wisenbilt (2010: 497) researched the purchase intention, or the desire/intention of consumers to buy a particular product. Buying intention can be measured by the likelihood of a consumer to buy the product. The higher the consumer interest in the purchase, the higher will be the consumer desire to buy that product. In consumer behavior, buying intention is very often associated with a conative component. Kotler, Armstrong, Harker, and Brennan (2009: 475) through the AIDA models describe the stages through which consumers ultimately determine the attitude of a product.

\section{Research Hypothesis}

Based on the empirical and theoretical review, a research hypothesis of this study is: there is a significant effect of the variable Sexual Advertising Appeal on consumers' intention to buy AXE products.

\section{Method}

The scale used in this study was an ordinal five-point Likert scale with a one shot or cross-sectional method. Usable 120 questionaires were used. The primary data collection was achieved by distributing questionnaires to the respondents through an online survey. Before completing the questionnaire, respondents were asked to watch via You Tube the AXE television commercial "Heaven on Earth". The link to the ads were given. The study consisted of two variables, namely one independent variable and one dependent variable. The independent variable $(X)$, is sexual advertising appeal consists of three sub variables: Physical Characteristics (X1), Sexually - Oriented Conduct (X2), Model's Sex Appeal (X3). The Dependent variable (Y), i. e. buying intention consists of four sub variables: Attention (Y1), Interest (Y2), Desire (Y3) and Action (Y4).

\section{Results and Discussion}

The results show that the variable of the advertising's sexual appeal has a very strong result with an average index of 4 . 24 (see Table 1.)

Table 1. Advertising's Sexual Appeal Scores

\begin{tabular}{|l|l|l|l|}
\hline \multicolumn{1}{|c|}{ Dimension } & Indicator & Index & Category \\
\hline \multirow{3}{*}{ Physical Characteristics } & The suitability of the age of the models for the advertisement & 4.25 & Very suitable \\
\cline { 2 - 4 } & The interest in physical shape of the models & 4.43 & Very interested \\
\cline { 2 - 4 } & Appropriate clothing revealment & 3.97 & Appropriate \\
\hline \multirow{3}{*}{ Sexually-Oriented Conduct } & Sexuality of physical activity & 4.29 & Very sexy \\
\cline { 2 - 4 } & Sexuality of voice and textual expression & 3.99 & Sexy \\
\cline { 2 - 4 } & Sexuality of physical contact & 4.09 & Sexy \\
\hline \multirow{3}{*}{ Model's Sex Appeal } & Physical beauty of models & 4.41 & Very beautiful \\
\cline { 2 - 4 } & Sexiness of models & 4.49 & Very sexy \\
\cline { 2 - 4 } & Status as a sex object & 4.28 & Strongly agree \\
\hline & Total & 38.2 & \\
\hline & Average Index & 4.24 & Very Good \\
\hline
\end{tabular}

Source: Data used for this research

The results summary indicates some diversity of sexual advertising appeal for each indicator. The highest score from the indicators of 4. 49 was obtained from the sexiness of the models indicator that formed part of the model's sex appeal dimension. This dimension also had a very high score for the two other indicators, namely the physical beauty of the 
model and their status as sex objects. Therefore it can be concluded that the higher the sexual attractiveness of the models, the higher will be the potential to attract the attention of the targeted audience.

The lowest score obtained of 3. 97 was from the clothing revealment indicator. Whilst a score of 3. 97 is still relatively high, it also indicates that that the audience exhibited a tendency to oppose clothing that was too blatant or overt. Therefore, in Indonesia some evidence can be given that if female models within advertisements have too revealing clothing, then the advertisement may not be able to perform the intended function of creating positive desires, preferences, beliefs and purchase intention for the advertised product or service.

The study result may further indicate that Indonesians still hold their eastern culture tightly. That is, that there is still some behavior that is considered too inappropriate to be seen. Perhaps understandably the way Indonesians dress is still heavily influenced by Muslim culture, where women are required to wear modest clothing.

Table 2. indicates the summary of scores for each indicator variable that make up purchase intention. Overall, purchase intention is seen to be quite high with an average index of 3. 275 .

Table 2. Purchase Intention Score

\begin{tabular}{|l|l|c|l|}
\hline Dimension & Indicators & Index & Category \\
\hline \multirow{2}{*}{ Attention } & Interested in the way information is given & 3.81 & Interested \\
\cline { 2 - 4 } & Believe in the benefit of the product & 3.22 & Quite believe \\
\hline Interest & Interested to buy product & 3.44 & Interested \\
\hline Desire & Willingness to try the product & 3.41 & Willing \\
\hline Action & Tend to buy the product & 3.07 & Tend to \\
\cline { 2 - 4 } & Sure to buy the product & 2.7 & Quite sure \\
\hline \multicolumn{1}{|c|}{ Total } & 19.65 & \\
\hline \multicolumn{2}{|c|}{ Mean } & 3.28 & Quite good \\
\hline
\end{tabular}

Source: Data used for this research

The purchase intention scores indicate some diversity in each indicator. The highest score obtained was 3. 81 from the indicator interested in the way information is given. This score could indicate the strong advertising power of sexual attraction. The Attention dimension is further supported by a relatively strong score for belief in the benefit of the product.

The lowest score obtained from indicators was sure to purchase the product (2. 7). This is understandable as strong interest will not always directly equate with exactly the same equally strong intention to buy. There could also be the possibility that the audience feels that an alternative to AXE products may exist.

Table 3. Coefficient of Determination

\begin{tabular}{|c|c|c|c|c|}
\hline \multicolumn{5}{|c|}{ Model Summary } \\
\hline Model & $\mathrm{R}$ & $\mathrm{R}$ Square & Adjusted R Square & Std. Error of the Estimate \\
\hline 1 & $.386^{\mathrm{a}}$ & .149 & .140 & 3.63613 \\
\hline
\end{tabular}

a. Predictors: (Constant), sexual appeal advertising

From statistical calculations in table 3 it can be seen that the correlation coefficient $(R)$ between the variables of sexual advertising appeal and the purchase interest is 0.386 . The positive correlation indicates that the relationship is unidirectional, whereby the higher the sexual appeal of advertising; the higher will be the buying intention. According to Taylor (2010: 37) a value of 0.386 (within the range interval $0.36-0.67$ ) indicates that there is a strong relationship between sexual appeal advertising $(\mathrm{X})$ and buying intention $(\mathrm{Y})$

Results further indicate that the coefficient of determination $\left(R^{2}\right)$ was 14. $9 \%$. This indicates that the variable of sexual advertising appeal contributes $14.9 \%$ to buying intention. The remaining $85.1 \%$ is influenced by other factors not included in the model, which may include product quality, price, consumer lifestyle, etc. 
Table 1.4. Regression results

\begin{tabular}{|c|c|c|c|c|c|c|}
\hline & \multirow{2}{*}{ Model } & \multicolumn{2}{|c|}{ Unstandardized Coefficients } & Standardized Coefficients & \multirow{2}{*}{$\mathrm{t}$} & \multirow{2}{*}{ Sig. } \\
\hline & & B & Std. Error & Beta & & \\
\hline \multirow{2}{*}{1} & (Constant) & 9.668 & 3. 158 & & 3. 061 & .003 \\
\hline & TX & .305 & .074 & .386 & 4. 139 & .000 \\
\hline
\end{tabular}

Table 1. 4 indicates a beta coefficient of 0.386 . This shows that there is a positive relationship between sexual appeal advertising $(X)$ and buying intention $(Y)$.

It can also be seen that: -

The t stat was 4. 139

$\mathrm{df}=98$ and $\alpha=0.05$ level of significance level of the test is two-way:

Table: -1. 984467 and 1. $984467 \mathrm{t}$ stat: 4. 139. From the calculation, it can be seen that $4.139>1.98$ or $t$ stat $>t$ table. So it can therefore be concluded that hypothesis $\mathrm{H} 1$ is supported. That is, there is a significant effect of the variable Sexual Advertising Appeal on consumers' intention to buy AXE products.

\section{Conclusions and Future Research}

The consumer response to AXE's products through the "Heaven on Earth" advertising commercial is very strong. This is indicated by the average index of 4. 24. Male Indonesian consumers in the age of 15-24 responded very positively to AXE products' sexual appeal in advertising measured via physical characteristics, sexually oriented behavior, and sexually attractive female models. This points out that Unilever succeeded in forming a powerful advertising message through sexual attraction that evoked an emotional response in the form of attention.

The potential for consumers to buy the product after seeing an AXE advertisement from the series "Heaven on Earth" is quite strong. This is shown by the average index achieved of 3. 28. Consumers responded well to paying attention and learning the value of the product. Respondents indicated a willingness and desire to try and buy the product. However, respondents were not ascertain to purchase or use the product.

Sexual advertising conducted by Unilever indicate a significant positive influence on consumer buying intention of AXE products, with a t value: $4139>t$ table: 1 . 98. The study resulted in the regression equation $Y=9.668+0.386 X$, where each increase in sexual advertising appeal $(X)$ should correlate to buying intention $(Y)$ increasing by 0386 . Sexual advertising appeal influenced buying intention by $14.9 \%$. The remaining $85.1 \%$ can be understood as the influence of other factors that are not incorporated into the model.

Of the three dimensions of sexual appeal advertising (Physical Characteristics, Sexually-Oriented Conduct and the models' sexual appeal), it can be seen that the models' sexual attraction is the most powerful in Indonesian advertising. In pursuing a path of sexual appeal in advertising, advertisers must therefore be highly selective in choosing advertising models that can represent and evoke sexual attraction. In order to achieve this, advertisers can conduct a sample survey of potential target-profiled customers to ensure that the model is selected according to the preferences of consumers. This will help to minimize an unfavorable image of the brand and the products offered. The selected model should not only have high sex appeal, but also a good reputation so as to improve the image of the brand and the products offered.

The survey results through the clothing revealment indicator show that respondents are sensitive to the appropriateness of clothing. Therefore, Indonesian companies need to establish clear boundaries of acceptable aspects of nudity so that these dimensions do not attract negative attention from consumers who could easily form negative associations and reactions to the brand and the products offered. Sexual attraction only explains a small portion of the commercial appeal of advertising. To maximize the advertising power of sexual attraction, companies must be able to create advertisements that are not only attractive, but also convincing and able to convey to customers the value of the products offered. Furthermore, companies may be able to support the advertising power of sexual attraction by conducting integrated marketing communication such as the bundling promotions to encourage consumers to buy.

It is suggested that future researchers could conduct advanced research related to sexual appeal advertising effect models and consumers buying intention. Researchers could also develop this study by using other respondents such as females and those from other age groups. Furthermore, sexual advertising appeal in the print and radio mediums could be explored. 


\section{References}

Aaker, David. , Day V. Kumar, \& S. George. Marketing Research. New York: John Wiley \& Sons.

Belch, George E. , and Michael A. Belch. 2009. Advertising and Promotion: An Integrated Marketing Communication Perspective, $8^{\text {th }}$ Edition. San Diego: McGraw-Hill

Bello, D. C. , M. J. Etzel, \& R. E. Pits. 1983. The Communication Effects of Controversial Sexual Content in Television Programs and Commercials. Journal of Advertising, 3 (12), 32-42.

BPS Kota Bandung. 2012. Penduduk Kota Bandung Menurut Kelompok Umur Tahun 2012. Accessed on 2 Januari 2014, from http: //bandungkota. bps. go. id/subyek/penduduk

Dewan Periklanan Indonesia. 2007. Etika Pariwara Indonesia: Tata Krama dan Tata Cara Periklanan Indonesia. Jakarta: Dewan Periklanan Indonesia.

Effendy, Onong Uchjana. 2002. IImu Komunikasi, Teori, dan Praktek. Bandung: Remaja Rosda Karya.

Ferdinand, Augusty. 2002. Pengembangan Minat Beli Merek Ekstensi. Semarang: Badan Penerbit Universitas Diponegoro.

Hasan, Iqbal. 2006. Analisis Data Penelitian Dengan Statistik. Jakarta: Bumi Aksara.

Hoffman, Griffin, \& Simpson. 2005. Marketing Principles \& Best Practices, 3ed International Student Edition. Mason Ohio United States: Thomson South Western.

Kapplan, M. Robert and Dennis P. Saccuzo. Phsycological Testing Principles, Application and Issues. Pacific Grove: Brooks/Cole Publishing Company.

Kinnear, Thomas C. and James R. Taylor. 1995. Riset Pemasaran: Pendekatan Terpadu, Terjemahan Edisi Ketiga. Jakarta: Erlangga

Kotler, Philip, and Kevin Keller. 2012. Marketing Management, 14th edition Pearson International Edition. New Jersey: Prentice.

Kotler, Philip, Gary M. Armstrong, Michael Harker, \& Ross Brennan. 2009. Marketing: an Introduction, 9th Edition. Prentice Hall.

Kurniawan, Sigit. 2012. Strategi Axe Sudah Tepat. Accessed on 27 Desember 2013, from http: //www.the-marketeers.com/archives/ strategi-axe-sudah-tepat-sasaran. html\#. UsA5VdIW1mx

LaTour, Michael S. , \& Tony L. Henthorne. 1994. Ethical Judgements of Sexual Appeals in print Advertising. Journal of Advertising, Volume 23, Number 3, 81-90.

Lin, Carolyn A. 1998. Uses of Sex Appeals in Prime-Time Television Commercials. Sex Roles, 38, 5/6, 461-475.

Liu, F. , H. Cheng, \& J. Li. 2009. Consumer Responses to Sex Appeal Advertising: A Cross-cultural Study. International Marketing Review, 26, 501-520.

Maholtra, N. K. 2010. Marketing Research: An Applied Orientation 6th Edition. New Jersey: Prentice Hall.

Morisson, Alexander. 2007. Periklanan Komunikasi Pemasaran Terpadu. Jakarta: Ramdina Prakarsa.

Mulvey, Jeanette. 2012. Why Sex Sells... More Than Ever. Accessed on 27 Desember 2013, fromhttp: //www. businessnewsdaily. com/2649-sex-sells-more. html

Rhenald, Kasali. 2007. Manajemen Periklanan Konsep dan Aplikasi di Indonesia. Jakarta: PAU-Ekonomi.

Reichert, Tom. 2002. Sex in Advertising Research: A Review of Content, Effects, and Functions of Sexual Information in Consumer Advertising. Annual Review of Sex Research, 13, 241-273.

Reichert, T. , S. E. Heckler, \& S. Jackson. 2001. The Effects of Sexual Social Marketing Appeals on Cognitive Processing and Persuasion. Journal of Advertising, 30 (1), 13-27.

Riduwan, Achmad dan Engkos Kuncoro. 2008. Cara Menggunakan dan Memaknai Analisis Jalur (Path Analysis). Bandung: Alfabeta.

Schiffman, L. G. , L. L. Kanuk, \& J. Wisenblit. 2010. Consumer Behavior, $10^{\text {th }}$ Edition ed. New Jersey: Prentice Hall.

Sherman, Claire, \& Pascale Quester. 2005. The Influence of Product/Nudity Congruence on Advertising Effectiveness. Journal of Promotion Management, Vol. 11 (2/3), 61-89.

Subagyo, Ahmad. 2010. Marketing In Business, Studi Kasus UMK \& LKM, Edisi Pertama. Jakarta: Mitra Wacana Media.

Sugiarto, Catur and Virginie De Barnier. 2013. Sexually Appealing Ads Effectiveness on Indonesian Customers. European Journal of Business and Management, 5, 9, 125-135.

Sugiyono. 2010. Metode Penelitian Kuantitatif Kualitatif dan RnD. Bandung: Alfabeta.

Suliyanto. 2006. Metode Riset Bisnis. Yogyakarta: Andi Publishing.

Taylor, Richard. 2010. Interpretation of the Correlation Coefficient: A Basic Review, International Journal of Diagnostic Medical.

Till, Brian D. \& Michael Busler. 2000. The Match-Up Hypothesis: Physical Attractiveness, Expertise, and the Role of Fit on Brand Attitude, Purchase Intent, and Brand Beliefs. Journal of Advertising, 29, 3, 1-13.

Umar, H. 2009. Metode Penelitian untuk Skripsi dan Tesis Bisnis. Jakarta: Rajawali Pers.

Visetbhakdi, Arpavadee. 2011. The Effects of Sex Appeal Advertising on Thai Consumers' Emotional and Behavioral Responses. The AU Journal of Management, Volume 9, Number 1, 1-12.

http: //www. unilever. com/brands-in-action/detail/Axe/292063/accessed 3011024 